\author{
Zbigniew Janusz Ożdżyński \\ Zespół Szkół w Gąbinie
}

\title{
Szkolenie kierowców w warunkach globalizacji
}

Globalizacja polega na rozprzestrzenianiu się podobnych zjawisk i procesów ekonomicznych, politycznych, społecznych i kulturowych, niezależnie od stopnia cywilizacyjnego zaawansowania czy położenia geograficznego. Za jej początki powszechnie przyjmuje się lata 90. XIX w., a jej pionierami są takie firmy, jak: Ford, Singer, Gillette, National Cash Register. Na procesy globalizacyjne wpływ miały i mają organizacje międzynarodowe, m.in.: Bank Światowy, Międzynarodowy Fundusz Walutowy czy Organizacja Współpracy Gospodarczej i Rozwoju (OECD). Globalizacja jest procesem, w którym można wyróżnić następujące nurty główne:

- gospodarczy, charakteryzujący się utworzeniem światowej gospodarki umożliwiającej swobodny przepływ dóbr, usług i czynników wytwórczych,

- ekonomiczny polegający na konsolidacji firm powodującej powstawanie korporacji krajowych i międzynarodowych,

- techniczny, charakteryzujący się rozwojem transportu, komunikacji, telekomunikacji, szybkim przepływem informacji w mediach oraz szerokim wykorzystaniem Internetu,

- społeczno-kulturowy ujednolicający różnice kulturowe, prowadząc do lepszego zrozumienia innych narodowości. Także dziedziny takie jak film, teatr, muzyka stają się do siebie podobne, bez względu na to, w której części świata się znajdujemy,

- polityczno-ustrojowy, polegający na rozwoju nowych form rządów, a także mogący doprowadzić do rozszerzenia demokracji na wiele państw. Ujednoliceniu uległ również system walutowy, co ułatwiło m.in. wyjazdy zagraniczne. Dzięki globalizacji łatwiejsze są migracje do innych państw.

Szeroko rozumiany proces globalizacji i powiązane z nim zjawiska gospodarcze, społeczne i polityczne obejmujące swym zasięgiem wiele państw mają duży wpływ na bezpieczeństwo ruchu drogowego. Proces ten warunkują: rozwój technicznych środków komunikacji, liberalizacja handlu międzynarodowego i redukcja barier przepływu towarów oraz kapitału, czemu sprzyjają m.in. korzystne warunki polityczne i działalność organizacji światowych, np. MFW, WTO etc. (ryc. 1). Globalizacja jest procesem intensywnym i niemożliwym do zahamowania. Ma wiele ujęć i definicji, a rozwija się dzięki silnym dążeniom społeczeństw do poprawy warunków życia, przede wszystkim dzięki rozwojowi nowoczesnych technik i technologii. Dominujące ujęcia definicji globalizacji dotyczą uniwersalizmu, internacjonalizacji i liberalizacji (Micał 2008). Uniwersalizm w branży edukacji kierowców przejawia się ujednoliceniem przepisów ruchu drogowego, metod szkolenia, wzorów praw jazdy i innych dokumentów. Internacjonalizacja odnosi się do wzrostu międzynarodowego ruchu drogowego i zależności podmiotów uczestniczących w ruchu drogowym. Na drogach całego świata dominują te same problemy: zatłoczone ulice, wypadki wymagające podobnych przeciwdziałań i rozwiązań 
z zakresu bezpieczeństwa ruchu drogowego. Celem liberalizacji jest budowanie światowego ruchu drogowego bez granic, ponieważ globalizacja wiąże się z procesem międzynarodowej integracji przepisów ruchu drogowego i edukacji kierowców.

Ryc. 1. Uwarunkowania i czynniki sprzyjające procesowi globalizacji w branży motoryzacyjnej

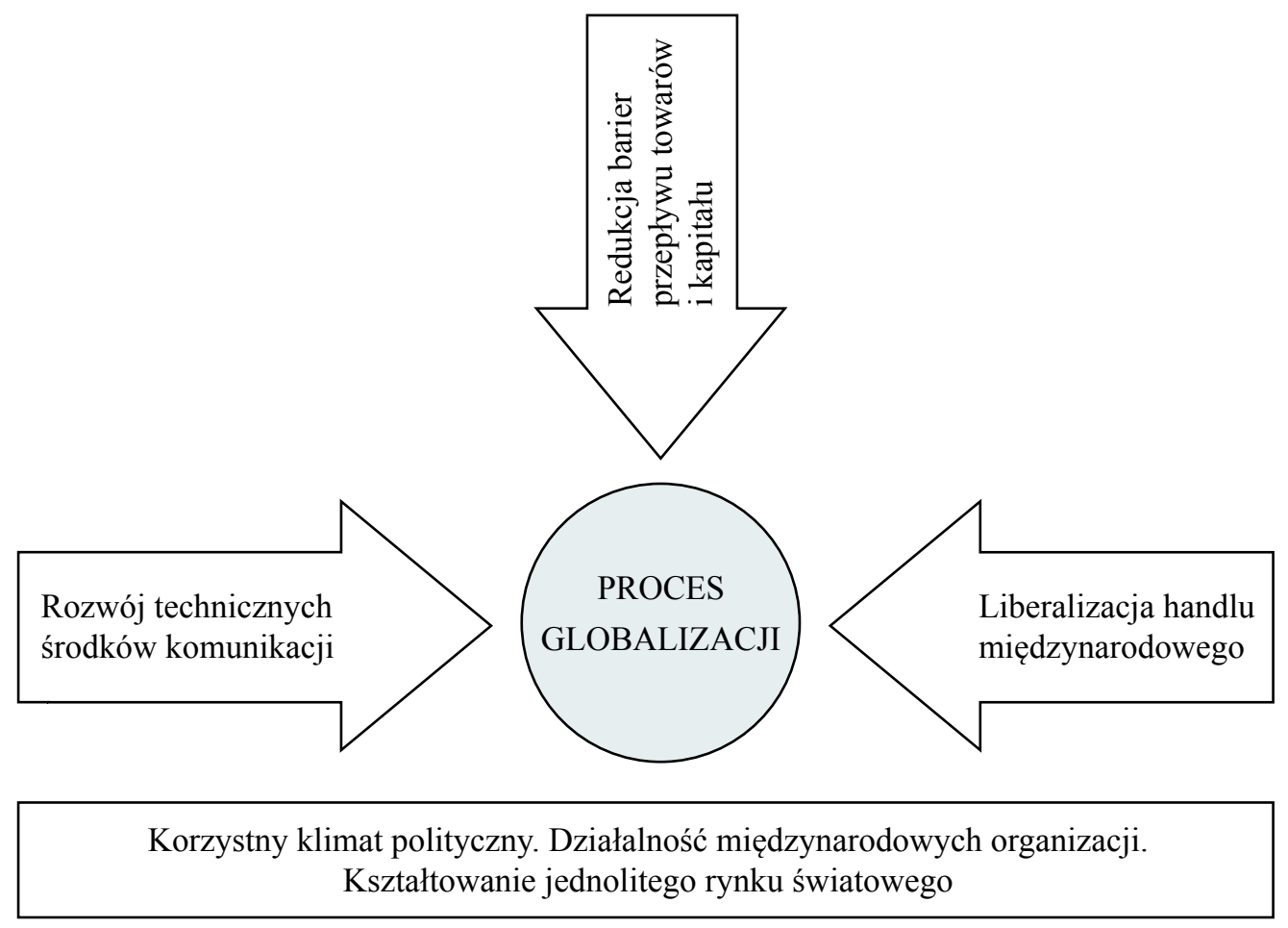

Źródło: Włodarczyk M., Janczewski J., Warsztaty samochodowe w warunkach globalizacji, referat wygłoszony na VII Ogólnopolskiej Metodycznej Konferencji Naukowej pt.: „Przedsiębiorczość w warunkach globalizacji”, w Zakładzie Przedsiębiorczości i Gospodarki Przestrzennej Instytutu Geografii Uniwersytetu Pedagogicznego im. Komisji Edukacji Narodowej w Krakowie w dniach 4-5 października $2010 \mathrm{r}$.

Płynność i bezpieczeństwo ruchu środków transportu drogowego to warunek szybkiego przepływu towarów i usług. Był on powodem opracowania nowej generacji przepisów regulujących międzynarodowy ruch środków transportu, w tym transportu drogowego. Można zatem stwierdzić, że opracowanie nowego modelu prawnego regulującego międzynarodowy ruch drogowy jest jednym z elementów procesu globalizacji. Proces ten warunkuje zmiany w obszarze edukacji kierowców w poszczególnych krajach. Międzynarodowy proces zmian przepisów ruchu drogowego rozpoczął się w 1968 r. w Wiedniu. W tym roku 58 państw sygnatariuszy podpisało Konwencję o ruchu drogowym. Wśród państw sygnatariuszy nie było Polski. Dopiero w roku 1984 Konwencja o ruchu drogowym została ratyfikowana przez Radę Państwa PRL z zastrzeżeniem art. 52 dotyczącego możliwości rozstrzygania sporów przed Trybunałem Sprawiedliwości. Zmiany polskiego modelu prawnego regulującego ruch drogowy zapoczątkowano w 1961 r. Jednak to rok 1983 należy przyjąć za datę rozpoczęcia procesu zmian dostosowujących polskie przepisy ruchu drogowego do wymagań ruchu międzynarodowego.

\section{Proces zmian przepisów o ruchu drogowym}

W procesie zmian polskich przepisów ruchu drogowego można wyróżnić cztery główne etapy: etap I - okres od 1945 r. do 1961 r., etap II - okres od 1961 r. do 1983 r., etap III - okres od 1984 r. do 1997 r. oraz trwający od 1998 r. etap IV (ryc. 2). 
Ryc. 2. Proces zmian polskich przepisów ruchu drogowego

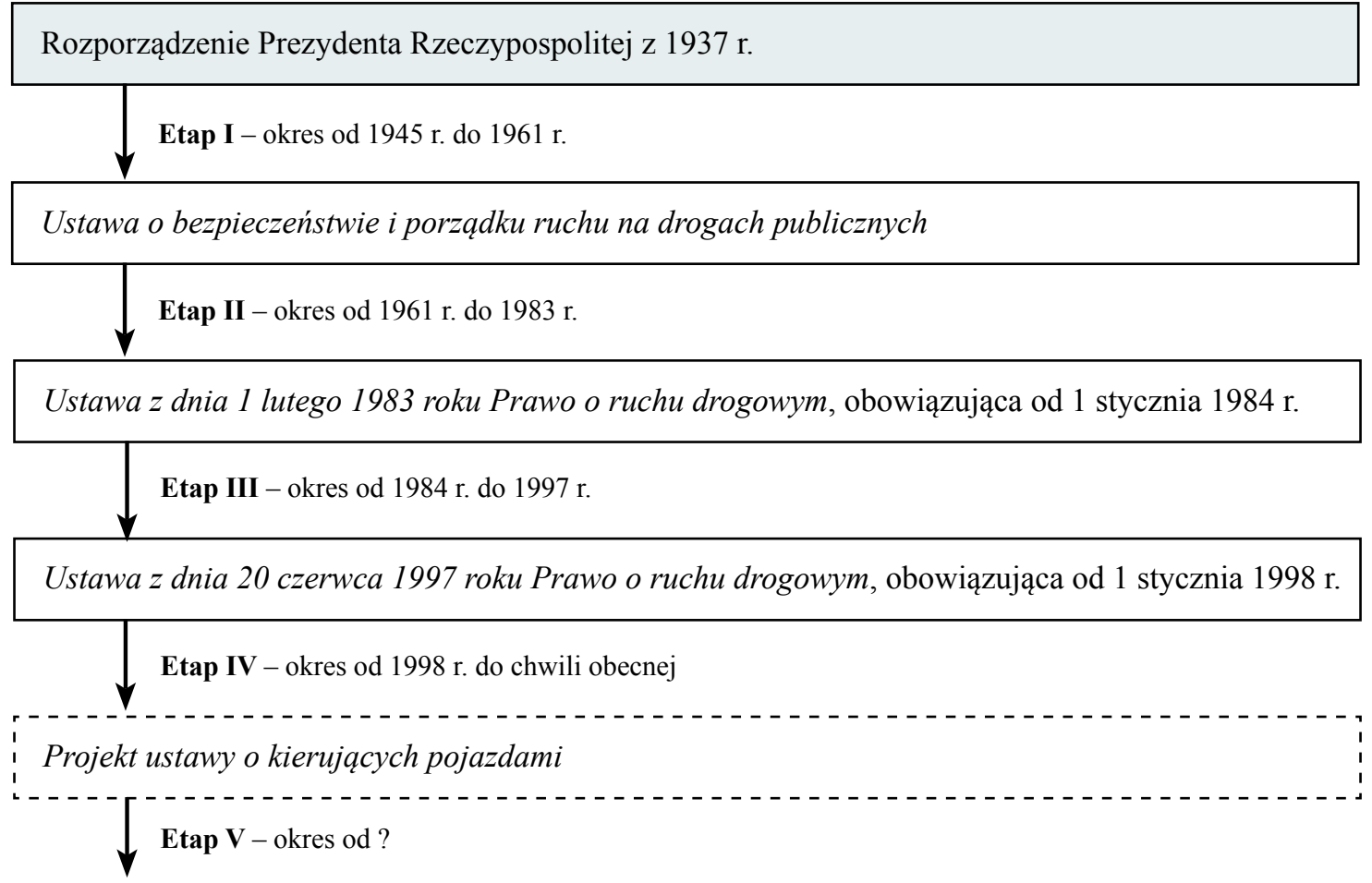

Źródło: opracowanie własne.

W fazie projektu jest Ustawa o kierujacych pojazdami. Wprowadzenie jej w życie zapoczątkuje $\mathrm{V}$ etap zmian polskich przepisów ruchu drogowego, dostosowując je do wymagań międzynarodowych.

Po zakończeniu II wojny światowej obowiązywało rozporządzenie prezydenta Rzeczpospospolitej z 1937 r., które wystarczająco regulowało ruch drogowy. Jednak rozwój motoryzacji przyczynił się do wzrostu natężenia ruchu pojazdów na drogach, przez co konieczne stało się dostosowanie przepisów ruchu drogowego. Proces ten rozpoczął się już w $1961 \mathrm{r}$. W listopadzie 1961 r. sejm wydał ustawę O bezpieczeństwie i porzadku ruchu na drogach publicznych, która weszła w życie 02.12.1961 r. i obowiązywała do końca 1983 r. Jednak rzeczywisty proces dostosowania przepisów do wymagań ruchu międzynarodowego rozpoczął się w 1983 r. z chwilą ogłoszenia ustawy Prawo o ruchu drogowym z mocą obowiązującą od 1 stycznia 1984 r. Przepisy tej ustawy w dużej części opierały się na przepisach wiedeńskiej Konwencji o ruchu drogowym. Kontynuacją procesu zmian dostosowujących polskie przepisy o ruchu drogowym do wymagań ruchu międzynarodowego jest obowiązująca od 1998 r. ustawa Prawo o ruchu drogowym i akty wykonawcze wydane na jej podstawie (Ożdżyński 2009). Projektowana Ustawa o kierujących pojazdami utrzyma rozwiązania, które się sprawdziły i wprowadzi wiele nowelizacji przepisów bezpośrednio dotyczących kierowców. Projekt ustawy wdraża postanowienia dyrektyw Wspólnoty Europejskiej, Parlamentu Europejskiego i Rady (EWG) ${ }^{1}$.

\footnotetext{
${ }^{1}$ Projekt ustawy dokonuje w zakresie swojej regulacji wdrożenia Dyrektywy $\mathrm{nr}$ 2006/126/WE Parlamentu Europejskiego i Rady z dnia 20 grudnia 2006 r. w sprawie praw jazdy (przekształcenie) (Dz.Urz. UE L 403 z 30.12.2006, s. 18) oraz częściowo Dyrektywy 2003/59/WE Parlamentu Europejskiego i Rady z dnia 15 lipca 2003 r. w sprawie wstepnej kwalifikacji i okresowego szkolenia kierowców niektórych pojazdów drogowych do przewozu rzeczy lub osób, zmieniajacej rozporzadzenie Rady (EWG) nr 3820/85 oraz dyrektywę Rady 91/439/EWG i uchylajacej dyrektywę Rady 76/914/EWG (Dz.Urz. UE L 226 z 10.09.2003, s. 4, z późn. zm.; Dz.Urz. UE polskie wydanie specjalne, rozdz. 7, t. 7, s. 441, z późn. zm.).
} 


\section{Proces zmian w edukacji kierowców kategorii B}

Proces globalizacji spowodował konieczność ujednolicenia przepisów w różnych dziedzinach gospodarki, kultury i edukacji, w tym w systemie edukacji kierowców. W etapie obowiązywania przepisów z 1937 i 1961 r. szkolenie podstawowe obejmowało budowę i naprawę pojazdu, a także szkolenie teoretyczne w zakresie przepisów i szkolenie praktyczne w zakresie techniki jazdy. Szkolenie w zakresie pozwoleń na prowadzenie pojazdów o dopuszczalnej masie całkowitej powyżej 3,5 tony nie było uzależnione od posiadania pozwolenia na prowadzenie pojazdów o dopuszczalnej masie całkowitej poniżej 3,5 tony. Proces szkolenia trwający trzy miesiące kończył się egzaminem zdawanym przed kilkuosobową komisją. Egzamin składał się z dwóch części:

- teoretycznej, w której należało wykazać się umiejętnością naprawy uszkodzonego pojazdu oraz znajomością przepisów ruchu drogowego,

- praktycznej, obejmującej umiejętności prowadzenia pojazdu oraz zastosowania przepisów w rzeczywistym ruchu drogowym.

W etapie drugim szkolenie podstawowe składało się z części teoretycznej oraz praktycznej. Szkolenie w zakresie praw jazdy w kategoriach pozwalających na prowadzenie pojazdów o dopuszczalnej masie całkowitej powyżej 3,5 tony nie było uzależnione od posiadania prawa jazdy kategorii III. Posiadanie prawa jazdy kategorii II lub I nie upoważniało do prowadzenia pojazdów objętych innymi kategoriami. Istotną zmianą było wprowadzenie do części teoretycznej egzaminu standartowego testu wielokrotnego wyboru, w którym tylko jedna odpowiedź była prawidłowa. Testy wprowadzono pod koniec lat 70. XX w. W późniejszym okresie wprowadzono specyficzne testy wielokrotnego wyboru, w których prawidłowe są jedna, dwie lub trzy odpowiedzi. W części praktycznej należało zdać jednoczęściowy egzamin ze znajomości techniki jazdy w obecności egzaminatora oraz instruktora w pojeździe, w którym odbywała się nauka. Egzamin był przeprowadzany w tym ośrodku, gdzie odbywało się szkolenie.

Duże zmiany przyniósł etap III wprowadzony ustawą Prawo o ruchu drogowym z 1983 r. Przepisy ustawy wprowadzały m.in. następujące zmiany:

- powołanie do życia ośrodków egzaminowania,

- powołanie do życia instytucji egzaminatora,

- podział części praktycznej egzaminu na dwa etapy: w etapie pierwszym należało wykazać się umiejętnością wykonania 11 manewrów na placu; w etapie drugim następował egzamin w ruchu miejskim,

- zmniejszenie liczby godzin szkolenia teoretycznego do 10.

Przedstawione zmiany przepisów wymusiły zmiany form szkolenia, przenosząc jego ciężar z ruchu miejskiego na plac manewrowy i skracając jednocześnie czas poświęcony na szkolenie w ruchu miejskim. Skutkowało to obniżeniem poziomu nauczania, ponieważ przy tej samej liczbie obowiązkowych godzin szkolenia praktycznego znaczną ich część należało poświęcić na naukę parkowania prowadzoną na wyłączonym z ruchu placu manewrowym.

W etapie IV wprowadzonym ustawą Prawo o ruchu drogowym z dnia 20 czerwca 1997 r. dokonano szeregu zmian w procesie edukacji. Do najważniejszych należy zaliczyć: zwiększenie liczby godzin obowiązkowego szkolenia teoretycznego z 10 do 30 oraz praktycznego z 20 do 30, wprowadzenie do części praktycznej egzaminu elementów obsługi pojazdu, a także przydział instruktora prowadzącego i przeniesienie części zadań z placu manewrowego do ruchu miejskiego (więcej w Ożdżyński 2009). Te zmiany spowodowały częściowy powrót szkolenia do ruchu miejskiego.

Do najnowszych zmian związanych z edukacją kierowców należą zmiany wprowadzone przepisami Ustawy z dnia 22 lipca 2010 r. o zmianie ustawy - Prawo o ruchu drogowym oraz niektórych innych ustaw. Obowiązujący proces edukacji polskich kierowców przedstawiono na rycinie 3. 
Ryc. 3. Proces edukacji kierowców w poszczególnych etapach zmian polskich przepisów ruchu drogowego

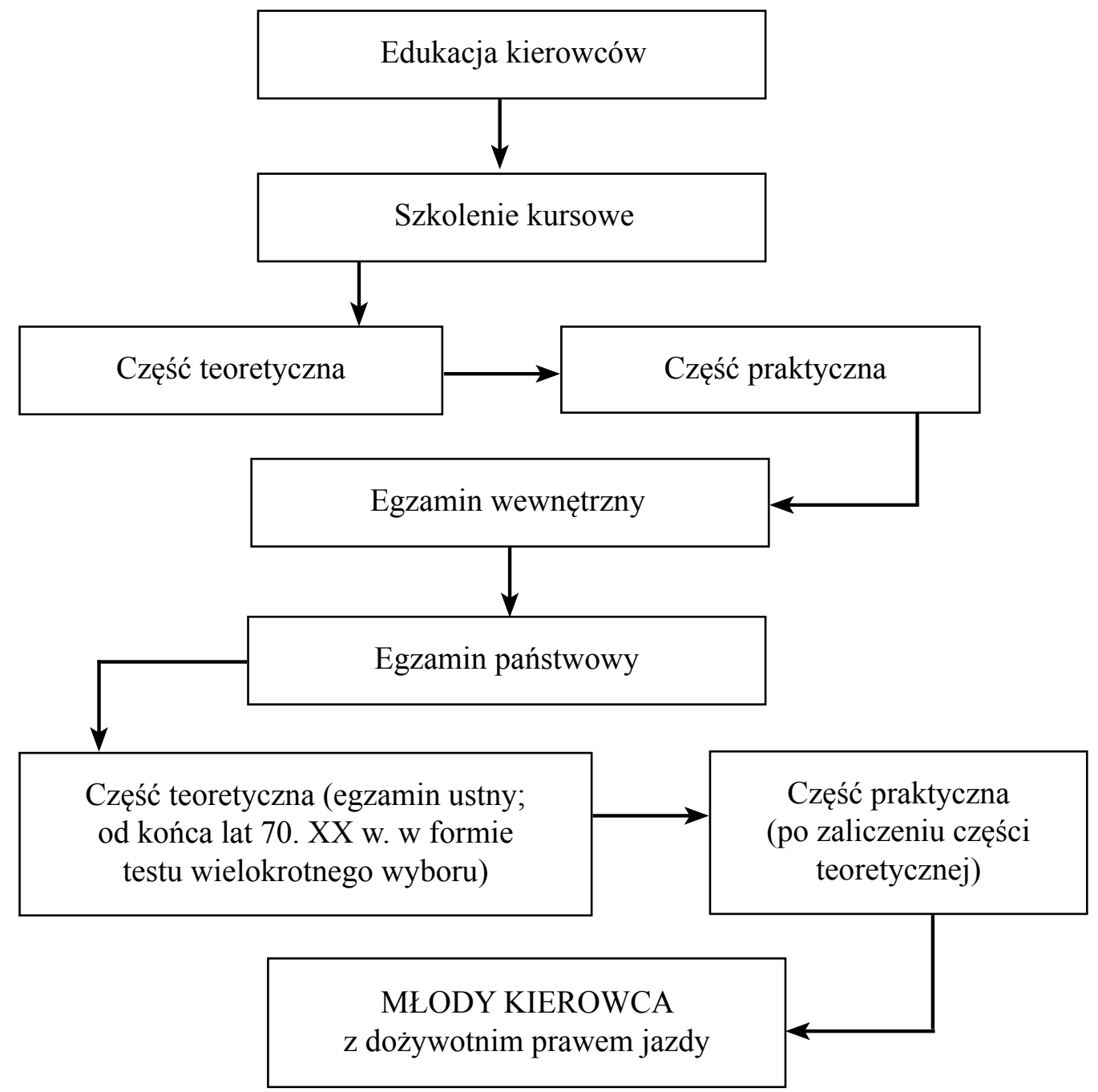

Źródło: opracowanie własne.

Przepisy wspomnianej ustawy m.in.:

- definiują pojęcie drogi publicznej, drogi wewnętrznej oraz strefy ruchu,

- rozszerzają stosowanie przepisów ruchu drogowego na drogi wewnętrzne położone w oznakowanych strefach ruchu.

Ustanowienie stref ruchu spowodowało konieczność ustalenia znaków oznaczających ich początek i koniec. Znaki te wprowadzone będą rozporządzeniem zmieniającym rozporządzenie w sprawie znaków i sygnałów drogowych (projekt rozporządzenia). Ich wzory przedstawiono na rycinie 4.

Ryc. 4. Projekt nowych znaków informacyjnych: a) znak „strefa ruchu”, b) znak „koniec strefy ruchu”

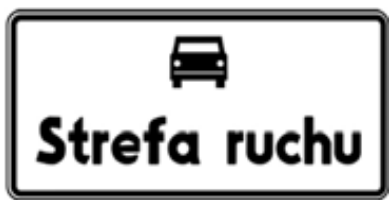

D-52

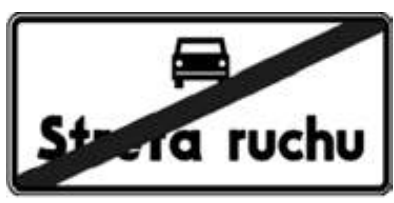

D-53

Źródło: Biuletyn Informacji Publicznej Ministerstwa Infrastruktury, Projekt rozporządzenia Ministrów Infrastruktury oraz Spraw Wewnętrznych i Administracji zmieniającego rozporządzenie w sprawie znaków i sygnałów drogowych, http://bip.mi.gov.pl/pl/bip/projekty_aktow_prawnych/projekty_rozporzadzen/ rozp_transport_drogowy/zna/px_17092010wa.pdf wrzesień 2010 
Etap V wprowadzony będzie Ustawą o kierujacych pojazdami, która od kilku lat jest w fazie szerokich konsultacji społecznych. Zgodnie z uzasadnieniem do projektu ustawy jej „głównym celem jest:

- poprawa bezpieczeństwa ruchu drogowego przez podniesienie kwalifikacji kierujących pojazdami,

- minimalizacja negatywnych zjawisk związanych z procesem uzyskiwania uprawnień do kierowania pojazdami, takich jak oszustwa, nierzetelne wykonywanie usług w zakresie szkolenia kierowców i korupcja" (Projekt ustawy o kierujacych pojazdami-uzasadnienie, wrzesień 2010).

Szczegółowe przepisy zaproponowane w Projekcie ustawy o kierujacych pojazdami utrzymują wszystkie wprowadzone do tej pory rozwiązania, które okazały się efektywne. Jednocześnie w projekcie zaproponowano nowe rozwiązania oparte na doświadczeniach europejskich krajów o wysokim stopniu rozwoju motoryzacji. Zmieni się także system uzyskiwania prawa jazdy kategorii B (ryc. 5). W projekcie zaproponowano również kilka istotnych zmian dotyczących osoby, która pierwszy raz uzyskała prawo jazdy kategorii B. Najważniejsze zmiany w systemie szkolenia to:

- wprowadzenie okresu próbnego trwającego dwa lata,

- wprowadzenie zakazu podejmowania pracy zarobkowej w charakterze kierowcy w zakresie przewozu osób w pierwszym roku okresu próbnego,

- wprowadzenie zakazu podejmowania osobiście działalności gospodarczej polegającej na kierowaniu pojazdem w zakresie przewozu osób w pierwszym roku okresu próbnego,

- wprowadzenie obowiązkowych kursów reedukacyjnych dla kierowcy, który w okresie próbnym popełnił dwa wykroczenia przeciwko bezpieczeństwu w komunikacji stwierdzone prawomocnymi wyrokami sądów lub przypisanymi punktami.

Ryc. 5. Model szkolenia reedukacji kierowców według Projektu ustawy o kierujących pojazdami

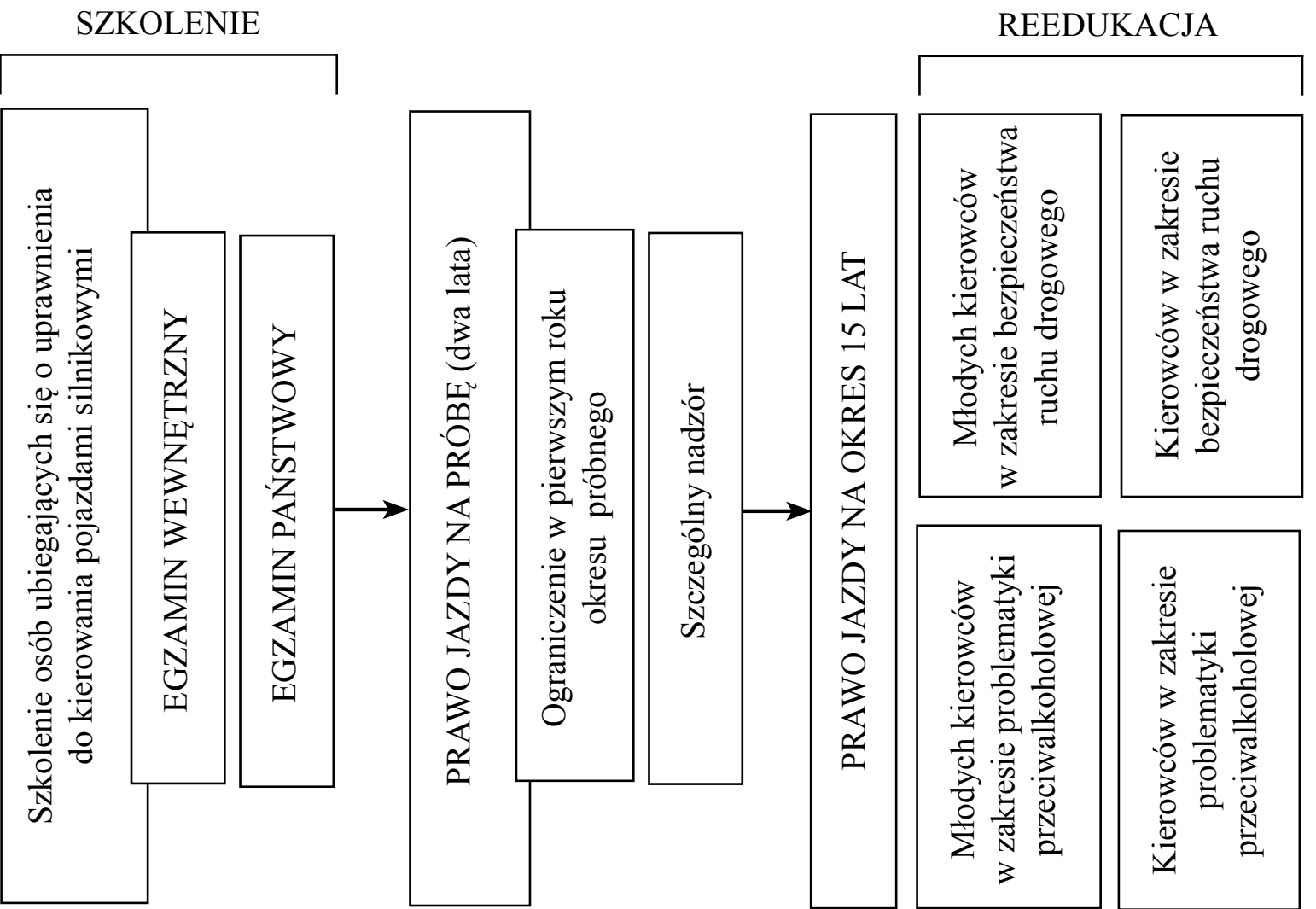

Źródło: opracowanie własne na podstawie Projektu ustawy o kierujących pojazdami. 
Proponowane zmiany koncentrują się na podniesieniu kwalifikacji kierowców. Ma to uzasadnienie w następujących faktach (uzasadnienie projektu ustawy):

- w grupie osób w wieku 18-24 lata posiadających prawo jazdy krócej niż dwa lata zanotowano tendencję wzrostową (o 10\%) ich udziału jako sprawców wypadków,

- w wypadkach z udziałem młodych kierowców 83\% zabitych są to również ludzie w wieku 18-24 lata,

- liczba ciężkich wypadków drogowych w Polsce jest trzykrotnie wyższa niż w krajach UE, a w wypadkach drogowych w Polsce w porównaniu z liczbą ludności ginie trzykrotnie więcej osób niż w krajach UE,

- w 73\% ośrodków szkolenia kierowców kontrolowanych przez Najwyższą Izbę Kontroli stwierdzono nieprawidłowości,

- egzamin teoretyczny zdaje za pierwszym razem 70,2\% kandydatów na kierowców, a egzamin praktyczny $32,7 \%$ kandydatów,

- 31\% zdających osób ocenia negatywnie sposób przeprowadzania egzaminów państwowych. Przyczyn tej niekorzystnej sytuacji jest wiele. Do najważniejszych należy zaliczyć niewłaściwy przebieg procesu nauczania kandydatów na kierowców (tab. 1).

Tab. 1. Niewłaściwy przebieg procesu nauczania kandydatów na kierowców jako czynnik wpływający niekorzystnie na stan bezpieczeństwa ruchu drogowego

\begin{tabular}{|l|l|l|}
\hline \multicolumn{1}{|c|}{ Cecha procesu nauczania } & \multicolumn{1}{|c|}{ Skutek } & \multicolumn{1}{c|}{ Ocena } \\
\hline $\begin{array}{l}\text { Niska jakość usług świadczonych } \\
\text { przez ośrodki szkolenia kierowców }\end{array}$ & $\begin{array}{l}\text { brak realizacji } \\
\text { programu }\end{array}$ & $\begin{array}{l}\text { kandydat jest nieprzygotowany } \\
\text { do uczestnictwa w ruchu drogowym }\end{array}$ \\
\hline $\begin{array}{l}\text { Ewidentne oszustwa polegające na } \\
\text { obietnicach typu ,u nas zdobędziesz } \\
\text { prawo jazdy w trzy dni” }\end{array}$ & $\begin{array}{l}\text { brak realizacji } \\
\text { programu }\end{array}$ & $\begin{array}{l}\text { kandydat jest nieprzygotowany } \\
\text { do uczestnictwa w ruchu drogowym }\end{array}$ \\
\hline $\begin{array}{l}\text { Nieuczciwa konkurencja w stosunku } \\
\text { do rzetelnych ośrodków szkolenia } \\
\text { kierowców }\end{array}$ & $\begin{array}{l}\text { brak pełnej } \\
\text { realizacji programu }\end{array}$ & $\begin{array}{l}\text { kandydat jest nieprzygotowany } \\
\text { do uczestnictwa w ruchu drogowym }\end{array}$ \\
\hline $\begin{array}{l}\text { Prowadzenie nauki wyłącznie pod } \\
\text { kątem egzaminu }\end{array}$ & $\begin{array}{l}\text { realizacja programu } \\
\text { pod kątem wykony- } \\
\text { wania manewrów }\end{array}$ & $\begin{array}{l}\text { Kandydat jest słabo przygotowany } \\
\text { do jazdy w ruchu miejskim }\end{array}$ \\
\hline $\begin{array}{l}\text { Brak właściwego nadzoru nad pracą } \\
\text { ośrodków szkolenia kierowców }\end{array}$ & błędy w szkoleniu & $\begin{array}{l}\text { kandydat jest słabo przygotowany } \\
\text { do jazdy w ruchu miejskim }\end{array}$ \\
\hline Afery łapówkarskie & handel egzaminami & $\begin{array}{l}\text { dopuszczenie do ruchu nieprzygoto- } \\
\text { wanych lub słabo przygotowanych } \\
\text { kandydatów }\end{array}$ \\
\hline
\end{tabular}

Źródło: opracowanie własne na podstawie Projekt ustawy o kierujących pojazdami - uzasadnienie, http://bip.mi.gov.pl/pl/bip/projekty_aktow_prawnych/projekty_ustaw/ustawy_transport_drogowy/ proj_ust_kieruj_pojazd wrzesień 2010

Ostatnie dziesięciolecie przyniosło również pozytywne doświadczenia i rozwiązania, do których należy zaliczyć:

- wprowadzenie jednolitych kryteriów oceny oraz ujednolicenie przebiegu egzaminów państwowych dla kandydatów na kierowców w całej Polsce, co umożliwiło m.in. powstanie wojewódzkich ośrodków ruchu drogowego, 
- wprowadzenie efektywnego systemu wydawania praw jazdy ograniczającego skutecznie zjawisko tzw. przestępstw przeciwko dokumentom,

- uregulowanie zasad wykonywania działalności gospodarczej w zakresie szkolenia kierowców,

- wprowadzenie systemu punktowej oceny kierowców mającego duże znaczenie dla profilaktyki w zakresie bezpieczeństwa ruchu drogowego.

W zakresie poprawy jakości procesu szkolenia w Projekcie ustawy o kierujących pojazdami zaproponowano następujące działania:

- podniesienie kwalifikacji wymaganych od instruktorów,

- zmiana wymagań w stosunku do ośrodków szkolenia kierowców,

- opracowanie standardów edukacyjnych przez wprowadzenie szczegółowych programów szkolenia określanych w drodze rozporządzenia przez ministra właściwego do spraw transportu,

- nałożenie na ośrodki szkolenia kierowców obowiązku przekazywania staroście dokładnych informacji o czasie, miejscu i osobach uczestniczących w kursie,

- sprecyzowanie uprawnień i obowiązków starosty w zakresie sprawowania nadzoru nad ośrodkami szkolenia kierowców,

- wprowadzenie nadzoru wojewody nad wykonywaniem zadań związanych ze szkoleniem kierowców przez samorząd szczebla powiatowego.

\section{Rola instruktora w procesie szkolenia kandydatów na kierowców}

W procesie szkolenia kandydatów na kierowców najważniejszą rolę odgrywa instruktor. Zakres proponowanych w Projekcie ustawy o kierujacych pojazdami zmian w stosunku do instruktorów przedstawiono $\mathrm{w}$ tabeli 2.

Tab. 2. Wymagania w stosunku do instruktorów zaproponowane w Projekcie ustawy o kierujących pojazdami

\begin{tabular}{|c|c|c|}
\hline \multicolumn{3}{|c|}{ Wymagania w stosunku do instruktorów } \\
\hline \multirow{2}{*}{ wykształcenie } & obecnie & po wejściu w życie ustawy \\
\hline & średnie & średnie \\
\hline $\begin{array}{l}\text { Posiadanie } \\
\text { uprawnień do } \\
\text { kierowania }\end{array}$ & $\begin{array}{l}\text { posiadanie prawa jazdy odpowiedniej } \\
\text { kategorii przez okres min. trzech lat }\end{array}$ & $\begin{array}{l}\text { posiadanie prawa jazdy kategorii B przez } \\
\text { okres min. trzech lat oraz prawa jazdy } \\
\text { odpowiedniej kategorii przez okres min. } \\
\text { roku }\end{array}$ \\
\hline Stan zdrowia & $\begin{array}{l}\text { brak przeciwwskazań zdrowotnych do } \\
\text { kierowania pojazdem }\end{array}$ & $\begin{array}{l}\text { brak przeciwwskazań zdrowotnych } \\
\text { do pracy na stanowisku instruktora }\end{array}$ \\
\hline $\begin{array}{l}\text { Sprawność } \\
\text { psychiczna }\end{array}$ & $\begin{array}{l}\text { brak przeciwwskazań psychologicz- } \\
\text { nych do kierowania pojazdem }\end{array}$ & $\begin{array}{l}\text { brak przeciwwskazań psychologicznych } \\
\text { do pracy na stanowisku instruktora }\end{array}$ \\
\hline Przeszkolenie & kurs kwalifikacyjny & $\begin{array}{l}\text { kurs prowadzony przez posiadający } \\
\text { poświadczenie Ośrodek Szkolenia } \\
\text { Kierowców }\end{array}$ \\
\hline $\begin{array}{l}\text { Potwierdzenie } \\
\text { posiadania } \\
\text { kompetencji }\end{array}$ & $\begin{array}{l}\text { egzamin kończący kurs i egzamin } \\
\text { przed komisją powołaną przez } \\
\text { wojewodę }\end{array}$ & $\begin{array}{l}\text { egzamin kończący kurs i egzamin przed } \\
\text { komisją powołaną przez wojewodę }\end{array}$ \\
\hline
\end{tabular}




\begin{tabular}{|l|l|l|}
\hline $\begin{array}{l}\text { Doskonalenie } \\
\text { zawodowe }\end{array}$ & $\begin{array}{l}\text { brak obowiązku doskonalenia } \\
\text { zawodowego }\end{array}$ & $\begin{array}{l}\text { coroczne uczestnictwo w warsztatach } \\
\text { doskonalenia zawodowego }\end{array}$ \\
\hline Niekaralność & $\begin{array}{l}\text { za przestępstwo przeciwko bezpieczeń- } \\
\text { stwu ruchu drogowego }\end{array}$ & $\begin{array}{l}\text { za przestępstwo przeciwko bezpieczeństwu } \\
\text { w komunikacji, za przestępstwo w celu } \\
\text { osiągnięcia korzyści majątkowej i osobistej, } \\
\text { za przestępstwo przeciwko wiarygodności } \\
\text { dokumentów, za przestępstwo przeciwko } \\
\text { zdrowiu i życiu, za przestępstwo przeciwko } \\
\text { wolności seksualnej i obyczajności oraz za } \\
\text { prowadzenie pojazdu po użyciu alkoholu }\end{array}$ \\
\hline $\begin{array}{l}\text { Wymogi } \\
\text { formalne }\end{array}$ & wpis do ewidencji instruktorów & wpis do ewidencji instruktorów \\
\hline
\end{tabular}

Źródło: Projekt ustawy o kierujących pojazdami - uzasadnienie, http://bip.mi.gov.pl/pl/bip/projekty_aktow _prawnych/projekty_ustaw/ustawy_transport_drogowy/proj_ust_kieruj_pojazd wrzesień 2010

Analiza danych zawartych w tabeli wskazuje na istotne zmiany wymagań w stosunku do instruktorów. Dotyczą one:

- wymaganych badań lekarskich i psychologicznych, które mają być przeprowadzane pod kątem przeciwwskazań do wykonywania pracy na stanowisku instruktora, a nie jak dotychczas wyłącznie pod kątem przeciwwskazań do kierowania pojazdem,

- szkolenia kandydatów na instruktorów, gdzie proponuje się ich prowadzenie przez posiadające poświadczenie ośrodki szkolenia kierowców,

- doskonalenia zawodowego przez coroczne uczestnictwo w warsztatach doskonalenia zawodowego,

- rozszerzenia katalogu przestępstw eliminujących osobę z ewidencji instruktorów.

Ważną misją społeczną instruktora nauki jazdy jest przygotowanie przyszłego kierowcy do uczestnictwa w ruchu drogowym. Zadaniem instruktora jest wyposażenie go w odpowiedni zasób wiedzy i umiejętności konieczne do prowadzenia pojazdu w ruchu drogowym oraz ukształtowanie tych cech osobowości, które są niezbędne do bycia dobrym i odpowiedzialnym jego uczestnikiem. Dlatego sam instruktor musi mieć stosowne kwalifikacje psychologiczno-pedagogiczne, dzięki którym proces nauczania będzie przebiegał prawidłowo i efektywnie. Ponadto ważną umiejętnością w procesie nauczania jest asertywność rozumiana jako szacunek dla samego siebie, dzięki któremu możemy komunikować innym, jakie są nasze potrzeby i oczekiwania przy jednoczesnym uszanowaniu ich praw do wyrażania własnych potrzeb. Asertywność można rozumieć jako zachowanie, pewność siebie i dobrą samoocenę, porozumiewanie się, umiejętność samorealizacji. Instruktor czy wykładowca, od początku sprawiający wrażenie osoby komfortowo czującej się w swojej roli, dobrze zorganizowanej, nawiązujący kontakt wzrokowy, przyjaźnie uśmiechający się i serdecznie witający się z innymi, ma największe szanse na zdobycie zaufania kursantów. Rolą instruktora w trakcie szkolenia jest również wskazanie uczniowi jego mocnych i słabych stron, co pomoże mu w ocenie swoich predyspozycji w kierowaniu pojazdem. Od tego, jak uczeń będzie postrzegał siebie, swoją wiedzę, umiejętności oraz kondycję psychiczną, będą zależały podejmowane przez niego działania w ruchu drogowym. Instruktor powinien umieć ocenić stan i tempo przyswajania nowych treści przez ucznia oraz jego sprawność psychomotoryczną, a także ćwiczyć to, co sprawia szczególne trudności. Z zadań stawianych instruktorowi wynikają dwie funkcje: nauczyciela i wychowawcy (ryc. 6). 
Ryc. 6. Funkcje pełnione przez instruktora nauki jazdy

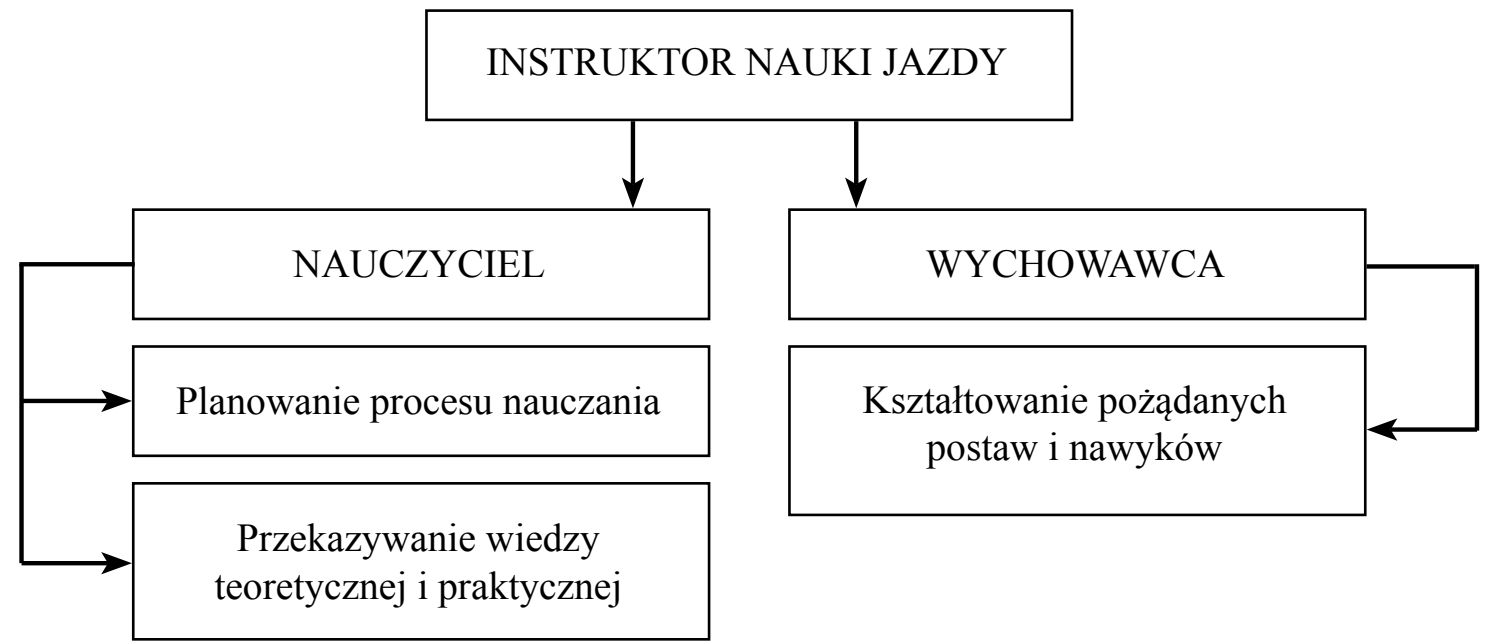

Źródło: Magierka M., Poradnik metodyczny dla instruktorów nauki jazdy - integralna część pakietu szkoleniowego Teka L-instruktor.pl, http://word.osk.net.pl/index.php/materiay-promocyjne, wrzesień 2010.

Instruktor jako nauczyciel jest odpowiedzialny za zaplanowanie procesu kształcenia, kierowanie nim oraz przekazywanie wiedzy teoretycznej i praktycznej. Jako wychowawca odpowiada za wychowanie uczniów poprzez kształtowanie pożądanych postaw i nawyków oraz formowanie systemu wartości, który motywuje do bezpiecznych zachowań na drodze i uwzględnia zasadę partnerstwa wobec innych uczestników ruchu drogowego. Projekt ustawy o kierujacych pojazdami wprowadza również obligatoryjne, cykliczne szkolenia kadry instruktorskiej, by utrzymywać i podnosić na wyższy poziom stan kompetencji i kwalifikacji w zakresie umiejętności szkolenia kandydatów na kierowców. Regularny udział w szkoleniach oraz praca samokształceniowa instruktorów umożliwi poprawę jakości procesu szkolenia kandydatów na kierowców, a tym samym poprawę bezpieczeństwa ruchu drogowego. Zaproponowane w Projekcie rozwiązania są również ogromną szansą przywrócenia instruktorom adekwatnego statusu. Pierwsze szkolenia kadry instruktorskiej rozpoczęły się w czerwcu 2010 r., przed wejściem w życie Projektu, w ramach unijnego projektu „Wzrost kompetencji kadr ośrodków szkolenia kierowców".

Wchodzące w życie w najbliższym czasie przepisy Projektu ustawy o kierujacych pojazda$m i$ (według Mikołaja Karpińskiego, rzecznika Ministerstwa Infrastruktury, najrealniejszy termin to połowa 2011 r.) powinny przynieść znaczne zmiany w procesie szkolenia kierowców. Rosnąca świadomość społeczna w zakresie bezpieczeństwa ruchu drogowego, konieczność poruszania się w międzynarodowym ruchu drogowym po krajach Unii Europejskiej doprowadzi do zmian organizacyjnych ośrodków szkolenia kierowców oraz unowocześnienia metod szkolenia kandydatów na kierowców w skali globalnej. Można oczekiwać, iż wejście w życie wspomnianego projektu ustawy wprowadzi Polskę do czołówki krajów o wysokich standardach bezpieczeństwa ruchu drogowego. Rynek edukacji kierowców w Polsce dysponuje dużymi rezerwami intelektualnymi i techniczno-organizacyjnymi, których nie wykorzystuje w pełni. Wprowadzenie przepisów Projektu powinno zmienić obecny rynkowy charakter usług edukacji kierowców na rywalizację w zakresie ich jakości. Siłą napędową tej zmiany jest potrzeba zapewnienia poczucia bezpieczeństwa uczestników ruchu drogowego. 


\section{Literatura}

1. Bąk J., 2003, Wypadki drogowe a kształcenie młodych kierowców, Instytut Transportu Samochodowego, Warszawa.

2. Bem Z., Olszańska A., 2008, Uczę jeździć samochodem. Wskazówki metodyczne dla instruktorów nauki jazdy, Grupa IMAGE, Warszawa.

3. Brown P., Globalizacja - szansa czy zagrożenie?, http://pl.shvoong.com/social-sciences/1683578globalizacja-szansa-czy-zagro\%C5\%BCenie/ sierpień 2010.

4. Globalizacja przedsiębiorstw i gospodarki - skutki i znaczenie globalizacji, http://globalizacja.genialne.info/ lipiec 2010.

5. Górny M., Lewandowska B., 2010, Metodyka nauczania dla kandydatów na instruktorów nauki jazdy, Grupa IMAGE, Warszawa.

6. Leśnikowska-Matusiak I. (red.), 2009, Bezpieczeństwo ruchu drogowego. Teoria i praktyka szkoleń, Instytut Transportu Samochodowego, Warszawa.

7. Magierka M., Poradnik metodyczny dla instruktorów nauki jazdy - integralna część pakietu szkoleniowego Teka L-instruktor.pl, http://word.osk.net.pl/index.php/materiay-promocyjne, wrzesień 2010,

8. Micał M., Proces globalizacji we współczesnym świecie, „Zeszyty Naukowe Zakładu Europeistyki Wyższej Szkoły Informatyki i Zarządzania w Rzeszowie", 3/2008 (8).

9. Ożdżyński Z., Zmiany procesu edukacji kierowców w warunkach integracji europejskiej, referat wygłoszony na VI Ogólnopolskiej Metodycznej Konferencji Naukowej pt. „Przedsiębiorczość w warunkach integracji europejskiej”, która odbyła się w Zakładzie Przedsiębiorczości i Gospodarki Przestrzennej Instytut Geografii Uniwersytetu Pedagogicznego im. Komisji Edukacji Narodowej w Krakowie w dniach 5-6 października 2009 r.

10. Projekt rozporządzenia Ministrów Infrastruktury oraz Spraw Wewnętrznych i Administracji zmieniającego rozporządzenie $w$ sprawie znaków $i$ sygnatów drogowych, Biuletyn Informacji Publicznej Ministerstwa Infrastruktury, http://bip.mi.gov.pl/pl/bip/projekty_aktow_prawnych/projekty_rozporzadzen/rozp_transport_drogowy/zna/px_17092010wa.pdf wrzesień 2010.

11. Projekt ustawy o kierujacych pojazdami, Biuletyn Informacji Publicznej Ministerstwa Infrastruktury, http://bip.mi.gov.pl/pl/bip/projekty_aktow_prawnych/projekty_ustaw/ustawy_transport_drogowy/ proj_ust_kieruj_pojazd wrzesień 2010 .

12. Projekt ustawy o kierujacych pojazdami - uzasadnienie, Biuletyn Informacji Publicznej Ministerstwa Infrastruktury, http://bip.mi.gov.pl/pl/bip/projekty_aktow_prawnych/projekty_ustaw/ustawy_transport_drogowy/proj_ust_kieruj_pojazd wrzesień 2010.

13. Włodarczyk M., Janczewski J., Warsztaty samochodowe w warunkach globalizacji, referat wygłoszony na VII Ogólnopolskiej Metodycznej Konferencji Naukowej pt.: „Przedsiębiorczość w warunkach globalizacji”, w Zakładzie Przedsiębiorczości i Gospodarki Przestrzennej Instytutu Geografii Uniwersytetu Pedagogicznego im. Komisji Edukacji Narodowej w Krakowie w dniach 4-5 października 2010 r.

14. Wzrost kompetencji kadr ośrodków szkolenia kierowców, projekt wspólfinansowany przez Unię Europejska w ramach Europejskiego Funduszu Społecznego w ramach Programu Operacyjnego Kapitat Ludzki, Działanie 2.1.1, http://word.osk.net.pl/index.php/home wrzesień 2010.

15. Ustawa z dnia 22 lipca 2010 r. o zmianie ustawy Prawo o ruchu drogowym oraz niektórych innych ustaw (Dz.U. Nr 152, poz. 1018), http://www.mi.gov.pl/2-48203f1e24e2f-1793054-p_1.htm wrzesień 2010. 


\section{Drivers Training in Conditions of Globalization}

The process of globalization makes it necessary to harmonize the regulations in various fields of economy, culture and education, including changes in the system of driver education. This paper presents the changes in Polish traffic law in the process of its adaptation to the international requirements and changes in driver training process in terms of improving road safety. It also identifies the areas of training that are undergoing the process of changes in conditions of globalization with emphasis on the role of instructor in the continuing education of drivers and improvement in their knowledge and skills. 